\title{
Comprehensive nursing care for a patient diagnosed with breast cancer
}

\section{Kompleksowa opieka pielęgniarska nad chorą z rozpoznaniem raka piersi}

\author{
Magdalena Wojtanowska-Kaczka ${ }^{A-F}$, Magdalena Babuśka-Roczniak ${ }^{B, C, E, F}$, Wojciech Roczniak ${ }^{A-D, F}$, Elżbieta Cipora ${ }^{A-F}$ \\ The Jan Grodek State University in Sanok \\ A - research concept and design; $B$ - collection and/or assembly of data; $C$ - data analysis and interpretation; \\ $\mathrm{D}$ - writing the article; $\mathrm{E}$ - critical revision of the article; $\mathrm{F}$ - final approval of the article
}

Pielęgniarstwo iZdrowie Publiczne, ISSN 2082-9876 (print), ISSN 2451-1870 (online)

Piel Zdr Publ. 2020;10(3):179-187

\section{Address for correspondence \\ Wojciech Roczniak}

E-mail: wojciech_roczniak@interia.pl

Funding sources

None declared

Conflict of interest

None declared

Received on April 20,2020

Reviewed on May 27, 2020

Accepted on August 20, 2020

\begin{abstract}
Breast cancer is the most frequently diagnosed cancer among both Polish and foreign women and is the main cause of their premature mortality. The aim of the manuscript was to present nursing activities focused on providing professional care for a patient diagnosed with breast cancer. The study covered a woman, aged 47, a resident of the Sanok poviat, who was diagnosed with right breast cancer in 2015 and underwent the necessary surgical treatment at the Oncological Surgery Department of the Specialist Hospital in Brzozów along with subsequent adjuvant treatment. The case study method was used. Patients diagnosed with breast cancer have many nursing problems both in the preoperative and postoperative periods. Many of those problems are of psychological nature. The nurse's individual approach to a patient allows for effective minimization and prevention of many of such problems. Nursing activities undertaken in relation to the patient had a major effect on her general condition. During the patient's stay in the hospital, she was provided with a sense of safety and well-being. The patient's deficient knowledge in the field of independent postoperative wound care and adjuvant treatment was supplemented. Proper provision of comprehensive nursing care for oncological patients is possible thanks to the constantly acquiring and updating knowledge in the field. Due to the constantly growing number of patients diagnosed with breast cancer, it is necessary to raise nursing care standards.
\end{abstract}

Key words: breast cancer, nursing, care, oncological surgery

Cite as

Wojtanowska-Kaczka M, Babuśka-Roczniak M, Roczniak W, Cipora E. Comprehensive nursing care for a patient diagnosed with breast cancer. Piel Zdr Publ. 2020;10(3):179-187. doi:10.17219/pzp/126574

DOI

$10.17219 / \mathrm{pzp} / 126574$

Copyright

○ 2020 by Wroclaw Medical University

This is an article distributed under the terms of the

Creative Commons Attribution 3.0 Unported License

(https://creativecommons.org/licenses/by/3.0/) 


\section{Streszczenie}

Rak piersi jest najczę́ciej diagnozowanym nowotworem nie tylko wśród Polek, ale i kobiet na całym świecie, będąc jednocześnie główną przyczyną ich przedwczesnych zgonów. Celem pracy było zaprezentowanie działań pielęgniarskich w sprawowaniu profesjonalnej opieki nad chorą, u której rozpoznano raka piersi. Badaniem objęto kobietę w wieku 47 lat, mieszkankę powiatu sanockiego, u której rozpoznano w 2015 r. raka piersi prawej oraz którą poddano koniecznemu leczeniu chirurgicznemu na Oddziale Chirurgii Onkologicznej Szpitala Specjalistycznego w Brzozowie i późniejszemu leczeniu uzupełniającemu. Wykorzystano metodę studium przypadku. U chorych, u których zdiagnozowano raka piersi występuje wiele problemów pielęgnacyjnych - zarówno w okresie przedoperacyjnym, jak i pooperacyjnym. Duża ich częśś ma podłoże psychologiczne. Indywidualne podejście pielęgniarki do chorej umożliwia skuteczne minimalizowanie oraz zapobieganie wielu z nich. Podjęte względem pacjentki działania pielęgniarskie miały ogromny wpływ na stan ogólny. W czasie pobytu pacjentki w szpitalu zapewniono jej poczucie bezpieczeństwa oraz poprawiono samopoczucie. Uzupełniono wiedzę z zakresu samodzielnej pielęgnacji rany pooperacyjnej oraz leczenia uzupełniającego. Skutecznie zredukowano strach oraz wynikający z niego stres. Właściwe sprawowanie kompleksowej opieki pielęgniarskiej wobec chorych na nowotwory jest możliwe dzięki ciągłemu zdobywaniu nowej i aktualizowaniu już posiadanej wiedzy. Ze względu na stale zwiększającą się liczbę pacjentów, u których rozpoznaje się raka piersi należy dążyć do podnoszenia standardów opieki pielęgniarskiej.

Słowa kluczowe: rak piersi, opieka, chirurgia onkologiczna, pielęgniarstwo

\section{Background}

The dynamic development of modern civilization has brought progress in many areas of human life. Medicine is a field of science that is constantly being innovated. Preventive, diagnostic and imaging tests, along with various forms of treatment, are constantly being amended in various medical specialties, including oncology, which deals with the diagnosis and its treatment of cancer. ${ }^{1-6}$ Despite such extensive development of oncology and subdisciplines, such as, e.g., oncological surgery, chemotherapy and radiation therapy, cancer is still a major health and social problem not only in Poland or Europe, but all over the world. ${ }^{7,8}$ Cancer affects both adults and children, developing in particular organs of the human body or in entire systems. ${ }^{9,10}$ According to WHO forecasts, tumors are to become the main cause of mortality in the global population in the coming years, replacing the dominant cardiovascular diseases. ${ }^{11}$

All cancers, including breast cancer, which is the subject of this manuscript, are specific diseases. ${ }^{12}$ The long period of treatment and convalescence require comprehensive and tailored care for patients. When focusing on holistic care of a patient diagnosed with cancer, we should keep in mind nursing, which is an important link in the broadly understood and coordinated structure of oncology.13

The formation and development in the field of medicine focusing on detection and treatment of pathological creations, such as cancer, gave birth to a new profession of nursing, namely oncological nursing. ${ }^{14}$ Oncological nurses participate in the care of patients diagnosed with cancer, which is a complex task requiring knowledge and skills to the greatest extent. ${ }^{15}$ These patients, in an extremely stressful situation, expect not only physical care, but also mental and spiritual support, which poses considerable challenges for modern nurses. ${ }^{16}$

Epidemiological reports signal a continuous increase in the number of new cases of malignant neoplasms, with breast cancer being the most frequently diagnosed cancer among Polish and foreign women, and the main cause of their premature mortality. ${ }^{17}$ Every year, around 1.4 million new cases of breast cancer are recorded around the world; therefore, every effort should be made to provide this group of patients with professional medical care, in which nurses' participation is of paramount importance. Proper nursing care for oncological patients is possible through constant acquisition and development of knowledge.

The aim of the manuscript was to present nursing activities focused on providing professional care for a patient diagnosed with breast cancer.

\section{Material and methods}

The study covered a woman, aged 47 , a resident of the Sanok poviat, who was diagnosed with right breast cancer in 2015 and underwent the necessary surgical treatment at the Oncological Surgery Department of the Specialist Hospital in Brzozów along with subsequent adjuvant treatment. The case study method was used. Interview and analysis of medical records have become the research techniques of choice. The research tools were the following: the patient's written consent to conduct tests, the author's questionnaire of the interview, complete medical documentation and the results of diagnostic tests. Disease acceptance scales (AIS), pain assessment (VRS) and patient's mental state (HDS) were also used.

\section{Case report}

The interview and acquired medical records showed that on August 21, 2015, a patient aged 45, detected a disturbing, hard right breast lump during breast self-examination. She decided to immediately consult a doctor. For 
this purpose, after her husband's previous registration, which he eventually cancelled, on August 26, 2015, she visited the General Surgery Clinic. A specialist doctor in the field of Oncological Surgery was in the doctor's office; therefore, the patient was admitted without a referral.

After the patient reported disturbing symptoms, which were the reason for her visit, the doctor undertook an examination to make a diagnosis.

According to the physical examination carried out by the doctor, the patient had been menstruating since the age of 14. Because of ovarian cysts, she was treated with hormonal agents (3 years). Condition after surgical removal of the cyst: 1 birth at 39 years of age, no miscarriages, breastfeeding 3 months, no history of breast disease, menstrual cycle to the present day (OM - August 15, 2015). Patient after holecystectomy: no addictions, sedentary lifestyle due to work, no history of cancers in the first line relatives. The physical examination showed unchanged symmetry and outlines of both breasts. Palpable tumour was identified in the upper lateral quadrant of the right breast without pressure soreness or other symptoms. The change was subjected to ultrasound assessment and, with the patient's consent, the material for histopathological examination was collected using BGI biopsy. The next appointment was set 3 weeks later, when the histopathological examination result were ready. Initial medical diagnosis: suspected breast cancer.

On September 16, 2015, the patient visited the General Surgery Outpatient Clinic again to receive the result of the histopathological examination of the material taken from the tumor, and to obtain information as to what to do next. The result left no doubt: ductal infiltrating cancer (GI) according to Elston-Ellis $(3+1+1) ; 70 \%$ positive estrogen receptors, $3+$ reaction intensity; $50 \%$ positive progesterone receptors, 3 + reaction intensity; HER receptor status - 2 negative - no reaction; E-cadherin - positive; $\mathrm{Ki}-6720 \%$. The patient received a referral to the Oncological Surgery Department in Brzozów. Information in the referral: malignant tumor (nipple, unspecified) - C 50.9.

The patient was admitted to hospital as planned based on the referral on October 5, 2015. The pateiint was treated for viral colitis with Asamax 500 mg. Drug allergies: ketoprofen, metamizole, penicillin, doxycycline. Basic life parameters were measured. Intravenous puncture was obtained and material for laboratory and serological tests was collected: blood group, Rh. Medical records were established. The patient was acquainted with the topography of the ward as well as her rights and obligations. She was qualified for breast-conserving therapy (BCT) with the procedure for determining and removing the sentinel-lymph node (BWW).

On October 6, 2015, the patient was prepared for surgery. A scintigraphic examination was performed to visualize and locate the "sentinel" node before the planned surgery for the right breast tumor. The marker was given with punctures at the border of the nipple areola. The gamma camera examination was performed $1.5 \mathrm{~h}$ after administration of the isotope. The marker accumulation in sentinel nodes is shown and the projections are marked on the skin with a marker (Fig. 1).

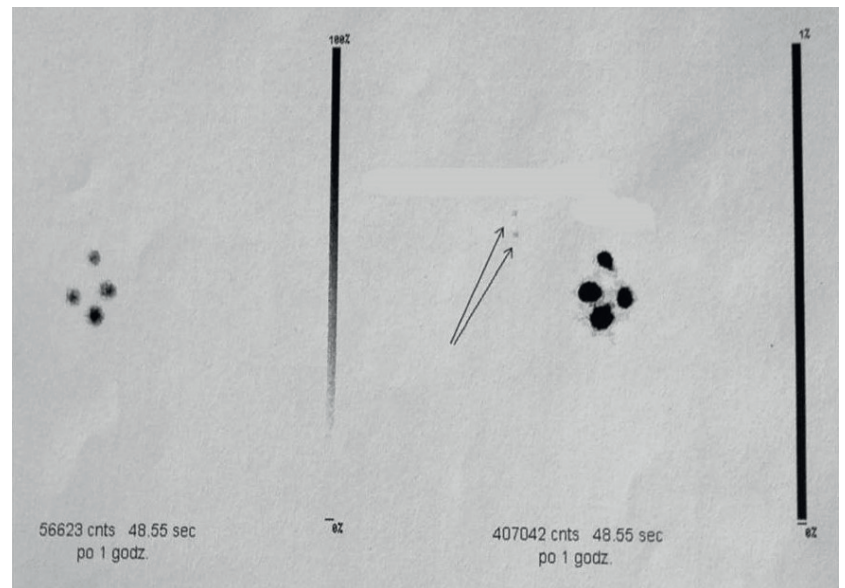

Fig. 1. Sentinel lymph nodes visible

Ryc. 1. Uwidocznione węzły chłonne wartownicze

The patient received fluids as ordered by the doctor (Plasmalyte - $500 \mathrm{~mL}$, glucose 5\% - $500 \mathrm{~mL}$ ). ECG was performer and the patient underwent anesthesiological consultation. The patient qualified for surgery under general endotracheal anesthesia. The patient's written consent for the procedure was obtained. Foley's bladder catheter was inserted during the procedure. Normal vital parameters were recorded at the time of transfer to the operating room (current entry in the fever card). Anthropometric values are important for anesthesia: weight $62 \mathrm{~kg}$, height $172 \mathrm{~cm}$. Blood was taken for laboratory tests and blood group determination. Extended monitoring was used. At 5:40 pm, the patient was given anesthesia. A quarter of an hour later, the scheduled operation began. The previously marked sentinel node and tumor were excised. Duration: $50 \mathrm{~min}$. Uncomplicated operational course. The cut-out structures were marked and sent for histopathological examination. At 6:45 pm, the patient was transferred to the Oncological Surgery Department. She was circulatory and respiratory efficient, awake and fully aware. The patient was transferred to the recovery room, where she was monitored. Postoperative orders were implemented (paracetamol 1 g, $1000 \mathrm{ml}$ Plasmalyte, $500 \mathrm{~mL}$ 5\% glucose). Intraoperative drainage and dressing condition was observed.

On October 7, 2015, the basic life parameters were without deviations from the norm. Post-operative wound drainage. The patient did not report any worrying ailments and was in good general condition. After the drains were removed by the doctor and the dressing changed, the patient was discharged home. Recommendations: check-up at the Oncological Surgery Clinic or Surgical Clinic in 7 days to remove sutures; check-up at the 
Oncological Surgery Clinic or Surgical Clinic after 14 days to receive the result of the histopathological examination and decision on further treatment; care for the surgical wound; rehabilitation. Final diagnosis - C 50.4 - malignant neoplasm (upper quarter of the outer nipple); right breast cancer - T1 N0 M0.

The histopathological assessment obtained on October 21, 2015, concerning the structures removed during surgery, reads as follows:

1. Two lymph nodes with non-specific inflammation, without metastasis $(0 / 2)$.

2. Three lymph nodes with non-specific inflammation, without metastasis (0/3).

3. G II invasive carcinoma of the right breast - pT1c. According to Elston-Ellis $(3+2+2)$. Fat tissue infiltration. Blockages in lymphatic vessels. In stroma - fibrosis and severe chronic inflammatory infiltrate. No top margin $0.7 \mathrm{~cm}$ deep. Margin $0.3 \mathrm{~cm}$ front. $0.5 \mathrm{~cm}$ deep. Bottom, at least $1 \mathrm{~cm}$. Side, at least $1 \mathrm{~cm}$. Medial, at least $1 \mathrm{~cm}$.

4. Fragment of cancer infiltrate removed with a $0.7 \mathrm{~cm}$ margin.

Based on the obtained histopathological examination result, the patient was referred to the Day Department of Chemotherapy and Oncological Hematology for adjuvant treatment.

On November 9, 2015, the patient underwent chemotherapy for the first time. Laboratory tests were normal. The patient obtained an application for a wig. Control morphology was recommended before undergoing the next series of chemotherapy. A prescription was issued for pharmaceuticals: Atossa and Emend - aimed at preventing nausea and vomiting in the course of chemotherapy.

On November 30, 2015, Mrs. A. M. received the $2^{\text {nd }}$ course of chemotherapy. Laboratory tests normal. The date of the next chemotherapy was set.

The $3^{\text {rd }}$ series of treatment was taken by the patient on December 21, 2015. We reported a slight decrease in individual blood count parameters (Table 1).

Continuation of pharmacological prevention of side effects of chemotherapy.

On January 11, 2016, when the $4^{\text {th }}$ course of chemotherapy was taken, cytostatic treatment was finished. Drug: Atossa - continuation, tamoxifen - initiation of hormone

Table 1. Selected parameters of patient's blood count

Tabela 1. Wybrane parametry morfologii krwi pacjentki

\begin{tabular}{|l|c|c|c|}
\hline Blood component & Result & $\begin{array}{c}\text { Relation to the } \\
\text { reference value }\end{array}$ & $\begin{array}{c}\text { Reference } \\
\text { value }\end{array}$ \\
\hline Leukocytes & 4.4 & - & {$[4.0-10.0]$} \\
Erythrocytes & 3.94 & $L$ & {$[4.00-5.20]$} \\
Hemoglobin & 11.9 & $L$ & {$[12.0-16.0]$} \\
Hematocrit & 35.2 & $L$ & {$[36.0-46.0]$} \\
Platelets & 330 & - & {$[150-400]$} \\
\hline
\end{tabular}

$L-10 w$. therapy. The patient was referred to the Radiotherapy Department. Recommendations: gynecological checkup twice a year; a visit to the Chemotherapy Outpatient Clinic 1 month after radiotherapy.

In the period from February 3, 2016 to February 24, 2016, the patient underwent radical irradiation of the mammary gland in 16 fractions and hormone therapy. Referred to the last treatment stage. Recommendations: on April 6, 2016, check-up at the Radiotherapy Clinic, continuation of hormone therapy, a calm and peaceful lifestyle, avoiding stressful situations, nurturing the irradiated area, following the recommended diet and drinking plenty of fluids.

The final stage of adjuvant treatment was a visit to the Brachytherapy Plant and a single irradiation of the affected tissues on February 25, 2016. After brachytherapy, a pressure dressing was applied for $24 \mathrm{~h}$.

The patient was finally discharged home after a welltolerated treatment.

\section{Results}

\section{The patient's general condition at the time of admission to hospital}

Upon admission to the Department of Oncological Surgery, the patient was able to move and perform everyday activities on her own. She was fully aware. Her memory was unchanged, had balanced mood and correct speech.

Life parameters were normal: blood pressure - 120/85 $\mathrm{mmHg}$, heart rate $-80 \mathrm{bpm}$, saturation - 99\%, temperature $-36.5^{\circ} \mathrm{C}$. Anthropometric parameters: weight $-62 \mathrm{~kg}$, height $-172 \mathrm{~cm}$.

The patient negated pain. She was focused on her health condition. She reported poor physical and mental state resulting from the diagnosis and necessity of hospitalization. The existing health situation was the greatest accumulation of stress in her life. The patient was worried about her own life and showed a clear deficit of knowledge in the field of possible forms of surgical treatment of breast cancer. She identified her hospital stay and surgical treatment with target mastectomy. She was afraid of disability resulting from the sickness. The patient reported sleep problems. Despite the great fear of treatment failure and death, supported by loved ones, she showed a great desire to live and recover. She did not allow the major stress resulting from the disease to paralyze her, and tried to think positively. She willingly cooperated with the medical staff. She carried out the instructions, complied with the recommendations. She accepted all medical examinations and procedures necessary for her in the treatment process.

The results of laboratory tests and serological tests marked at the doctor's request at the time of admission to the hospital (Table 2). 
Table 2. The results of laboratory and serological tests marked at the time of admission to the hospital

Tabela 2. Wyniki badań laboratoryjnych oraz serologicznych oznaczonych w chwili przyjęcia pacjentki do szpitala

\begin{tabular}{|c|c|c|c|}
\hline Test & Result & $\begin{array}{l}\text { Relation } \\
\text { to the } \\
\text { reference value }\end{array}$ & $\begin{array}{l}\text { Reference } \\
\text { value }\end{array}$ \\
\hline Blood type & & 0 Rh "-" (minus) & \\
\hline $\begin{array}{l}\text { Morphology } \\
\text { leukocytes } \\
\text { erythrocytes } \\
\text { hemoglobin } \\
\text { hematocrit } \\
\text { platelets }\end{array}$ & $\begin{array}{l}4.7 \\
4.13 \\
13.2 \\
37.1 \\
244\end{array}$ & $\begin{array}{l}- \\
- \\
- \\
- \\
-\end{array}$ & $\begin{array}{c}{[4.0-10.0]} \\
{[4.00-5.20]} \\
{[12.00-16.00]} \\
{[36.0-46.0]} \\
{[150-400]}\end{array}$ \\
\hline $\begin{array}{l}\text { Coagulation panel } \\
\text { APTT } \\
\text { PT }\end{array}$ & $\begin{array}{l}28.2 \\
1.07\end{array}$ & $\begin{array}{l}- \\
-\end{array}$ & $\begin{array}{c}{[25.4-36.9]} \\
-\end{array}$ \\
\hline $\begin{array}{l}\text { Biochemistry } \\
\text { glucose } \\
\text { urea } \\
\text { creatinine } \\
\text { sodium } \\
\text { potassium } \\
\text { chloride }\end{array}$ & $\begin{array}{c}4.87 \\
3.6 \\
70.00 \\
150 \\
5.0 \\
110\end{array}$ & $\begin{array}{l}- \\
- \\
- \\
H \\
- \\
H\end{array}$ & $\begin{array}{c}{[4.11-5.89]} \\
{[0.0-8.3]} \\
{[44.00-80.00]} \\
{[136-145]} \\
{[3.5-51]} \\
{[98-107]}\end{array}$ \\
\hline
\end{tabular}

APTT - activated partial thromboplastin time; PT - prothrombin time; $\mathrm{H}-$ high.

\section{Patient's problems with the diagnosed breast cancer: Planning, implementation and assessment of nursing activities}

\section{Nursing diagnoses - preoperative}

Diagnosis I: discomfort caused by the need to stay in the hospital.

Purpose of care: minimization of discomfort.

\section{Care plan:}

- familiarization with the topography of the department;

- showing support and understanding;

- conversation with the patient and hearing all the problems she reports;

- ensuring the patient's contact with loved ones;

- individual approach to the patient;

- ensuring safety and creating a friendly atmosphere for the patient;

- teaching the patient to perceive the hospital stay as the most important stage in the fight against the disease.

Assessment: the discomfort caused by the patient's stay in the hospital significantly decreased.

Diagnosis II: knowledge deficit of surgical treatment of breast cancer.

Purpose of care: educating the patient in breast cancer surgery.

\section{Care plan:}

- ensuring contact with the attending physician;

- explaining all concepts incomprehensible to her and doubts within the scope of nursing competence;
- informing and explaining all nursing activities undertaken in relation to the patient and discussing their purposefulness;

- informing the patient about proper preparation for the procedure and encouraging cooperation;

- providing the patient with information and educational materials on the surgical treatment of breast cancer.

Assessment: all doubts were clarified. The patient knows the surgical forms of breast cancer treatment.

Diagnosis III: fear of disability resulting from mastectomy. Purpose of care: minimizing anxiety.

\section{Care plan:}

- showing support and understanding;

- starting a conversation with the patient and trying to calm her down;

- ensuring contact with the family;

- ensuring contact with the doctor to get acquainted with the proposed surgical treatment;

- encouraging the patient to ask questions about the planned surgical breast treatment;

- ensuring a sense of safety.

Assessment: the patient's fear of disability as a result of mastectomy subsided. The patient was introduced to the individual surgical treatment plan.

Diagnosis IV: fear of treatment failure and death resulting from an ongoing cancer process.

Purpose of care: reducing anxiety, ensuring safety.

Care plan:

- ensuring the patient's contact with the attending physician and enabling a discussion of prognosis based on the histopathological examination obtained;

- providing the patient with information on the effectiveness of the treatment within the scope of nursing competence;

- enabling conversation with patients who have already undergone breast-saving treatments;

- presenting the patient an intraoperative management scheme and forms of possible complementary treatment.

Assessment: the level of anxiety felt by the patient decreased. The patient feels safe.

Diagnosis V: difficulty falling asleep due to stress.

Purpose of care: getting effective sleep.

\section{Care plan:}

- ensuring peace and quiet;

- encouraging the patient to listen to calm music or to read before bed;

- taking care of the right temperature in the sick room;

- airing the sick room;

- assistance for the patient taking a comfortable sleeping position for rest and relaxation;

- participation in pharmacotherapy as ordered by the doctor. Assessment: the patient falls asleep easily and wakes up rested. 
Diagnosis VI: fear of planned surgery to remove the breast tumor.

Purpose of care: reducing anxiety and ensuring a sense of safety.

\section{Care plan:}

- conversation and attempts to calm the patient down;

- discussing the need for surgery in the light of recovery with the patient;

- enabling contact with loved ones;

- informing the patient of all actions taken for her before the surgery and explaining their purpose;

- helping the patient to properly complete the anaesthesia history helpful during the consultation with the doctor;

- ensuring contact with doctors and persuading the patient to ask questions about anaesthesia and the course of surgery.

Assessment: the patient feels safe and anxiety was reduced.

Diagnosis VII: risk of urinary tract infection as a result of the Foley catheter inserted.

Purpose of care: prevention of complications due to bladder catheterization.

\section{Care plan:}

- patient catheterization in accordance with the principles of asepsis and antiseptics;

- informing the patient of the need to maintain proper perineal hygiene;

- changing the urine bag;

- diuresis control;

- observing the quality of accumulated urine;

- informing the patient about the need to report disturbing symptoms (e.g., pain or burning);

- body temperature control.

Assessment: no signs of urinary tract infection are found.

Diagnosis VIII: risk of infection of the peripheral cannula puncture site.

Purpose of care: minimizing the risk of infection.

Care plan:

- observation of the cannula injection site;

- daily changes of the puncture wrap;

- compliance with the principles of aseptic and antiseptic when using intravenous access;

- replacing the bag with a new one after unscrewing it from the cannula;

- responding to any complaints reported by the patient related to the inserted cannula.

Assessment: there were no adverse effects that could indicate a cannula site infection.

\section{Nursing diagnoses - post-operative}

Diagnosis I: postoperative wound pain resulting from tumor removal.

Purpose of care: fighting the pain.

\section{Care plan:}

- putting the patient in a convenient position;

- pain level control;

- reporting the occurrence of pain to the doctor;

- participation in pharmacotherapy as ordered by the doctor;

- checking the effectiveness of the pharmacotherapy used.

Assessment: the intensity of postoperative wound pain was significantly reduced.

Diagnosis II: risk of lymphoedema of the upper limb on the operated side.

Purpose of care: prevention of oedema of the upper limb.

\section{Care plan:}

- positioning the upper limb on the operated side in elevation using rehabilitation wedges;

- patient observation;

- encouraging and helping the patient to put on wide-sleeved pajamas;

- encouraging the patient to take up limb exercises on the operated side.

Assessment: there was a slight lymphoedema.

Diagnosis III: risk of post-operative wound infection as a result of the drains.

Purpose of care: prevention of infection.

Care plan:

- care for the post-operative wound;

- changing dressings in accordance with the principles of asepsis and antiseptics;

- proper wound care;

- drain patency control;

- documenting the amount and color of secretions drained from drains;

- participation in antibiotic therapy as ordered by the doctor.

Assessment: postoperative wound infection did not occur.

Diagnosis IV: nausea and vomiting as a result of anaesthesia.

Purpose of care: fighting nausea and vomiting.

\section{Care plan:}

- putting the patient in a position that prevents choking;

- administration of the vomiting and lignin bag;

- giving mouthwash;

- observation of the quantity and quality of vomiting;

- participation in pharmacotherapy as ordered by the doctor;

- airing the room;

- changing the patient's underwear and bed linen, if necessary.

Assessment: Nausea and vomiting subsided.

Diagnosis V: risk of postoperative complications.

Purpose of care: prevention of possible postoperative complications. 


\section{Care plan:}

- patient observation;

- monitoring basic vital parameters and their documentation;

- observation of wounds and drains;

- diuresis control;

- reporting any worrying symptoms to the doctor;

- participation in pharmacotherapy as ordered by the doctor.

Assessment: there were no post-operative complications.

Diagnosis VI: water and electrolyte disturbances may occur as a result of nausea and vomiting.

Purpose of care: preventing water and electrolyte disturbances.

\section{Care plan:}

- patient observation;

- keeping a fluid balance;

- participation in pharmacotherapy as ordered by the doctor;

- control of basic life parameters;

- participation in commissioned laboratory diagnostics;

- diuresis control;

- early response to disturbing symptoms;

- informing the doctor about all irregularities.

Assessment: no water-electrolyte disturbances were found.

Diagnosis VII: fear of the first mobilization after surgery. Purpose of care: reducing anxiety, ensuring safety, early mobilization.

\section{Care plan:}

- talking to the patient and calming her down;

- discussing the benefits of early mobilization after surgery with the patient;

- showing support and understanding;

- encouraging attempts to undertake physical activity;

- providing help and instructions to the patient during the first mobilization after the treatment;

- encouraging regular improvement exercises.

Assessment: anxiety was reduced. The patient willingly attempted physical activity. She felt safe.

Diagnosis VIII: knowledge deficit of self-care of the wound.

Purpose of care: educating the patient on proper postoperative wound care.

Care plan:

- instructing the patient on taking care of the wound;

- discussing the principles of aseptics and antiseptics;

- learning to control the wound healing process;

- indicating materials and resources needed to apply the dressing;

- learning how to properly apply a wound dressing;

- involving the family to help in proper wound care.

Assessment: the patient knows the principles of postoperative wound care and is able to apply them.
Diagnosis IX: fear of relapse.

Purpose of care: minimizing concerns and fears.

\section{Care plan:}

- encouraging the patient to undergo regular preventive examinations;

- learning how to control the body;

- discussing the importance of a balanced diet and a healthy and active lifestyle;

- ensuring contact with the doctor to indicate proper management after leaving the hospital (receiving a histopathological result, checking in specialist clinics, possible additional treatment);

- showing support and understanding;

- encouraging loved ones to spend time together in a way that diverts the patient's attention away from thoughts about the relapse.

Assessment: the fear of relapse has significantly diminished, but it has not completely disappeared.

Diagnosis X: knowledge deficit about adjuvant treatment.

Purpose of care: educating the patient in adjuvant treatment.

\section{Care plan:}

- theoretical discussion of forms of complementary treatment within nursing competences;

- providing the patient with information materials in the form of guides, leaflets and brochures;

- ensuring contact with the attending physician;

- encouraging asking questions to obtain proper knowledge.

Assessment: the patient knows the forms of adjuvant treatment.

Diagnosis XI: lack of appetite due to adjuvant treatment.

Purpose of care: restoring appetite.

\section{Care plan:}

- discussing the idea of a balanced diet in the fight against cancer;

- encouraging the patient to take physical activity before meals;

- urging the patient to eat smaller, but more frequent, portions of meals;

- encouraging the patient and her relatives to modify their diet;

- preparing meals willingly eaten by the patient.

Assessment: the patient eats meals with considerable difficulty.

Diagnosis XII: weakness and malaise caused by adjuvant therapy.

Purpose of care: improving mood.

\section{Care plan:}

- participation in laboratory tests;

- participation in pharmacotherapy as ordered by the doctor; 
- providing individualized nursing care;

- showing understanding and support;

- ensuring peace and quiet;

- observation;

- control of basic life parameters.

Assessment: the patient's well-being improved despite weakness.

\section{Discussion}

Diagnosis of a serious disease (breast cancer) that affects one of the most important attributes of femininity and the necessity of undertaking a long treatment is an extremely traumatic experience for every woman. ${ }^{19,20}$ It raises many problems, primarily psychological. Fear and tremendous stress accompany sick women from the moment of detecting disturbing symptoms through diagnostics to the end of the treatment, and often last continuously long after it. $^{21}$

In a wide range of problems diagnosed in patients with breast cancer, the following characteristic of the preoperative and postoperative periods can be distinguished.

Pre-operative problems include fear of disability. Patients often equate surgery for breast cancer with the need for a mastectomy. This is due to the lack of knowledge of the forms of treatment and selection of an appropriate method for the development stage of this cancer. Early detection of breast changes and the treatment greatly increases the chance of recovery and less radical methods of surgical treatment. In this case, prevention and regular breast self-examination, which allows for an early detection of pathological changes, are an inseparably linked. ${ }^{22}$

The individual case of a patient diagnosed with breast cancer used in this manuscript perfectly illustrates the essence of self-control. During breast self-examination, the patient detected a lump that turned out to be a malignant tumor at an early stage of development. Thanks to quick diagnostics and an immediate treatment, the patient was qualified for a mammary gland-conserving therapy and successfully underwent a long and complicated treatment process. ${ }^{21,22}$

Psychological problems in patients after tumor removal surgery are fear of relapse or the occurrence of metastases and fears associated with entering adjuvant treatment. These problems also result from the lack of knowledge. ${ }^{21}$

Many psychological problems can be effectively prevented while providing professional nursing care for a patient diagnosed with breast cancer. The role of a nurse is not limited to just caring for the patient physically. She has a major role in patient education and thus significantly affects the mental state. Showing understanding and support, and creating a sense of safety significantly improves the mental state of patients. Enabling contact with loved ones and an individual approach to the patient reduces fear. Familiarizing the patient with the purposefulness and the course of medical activities undertaken towards her allows for conscious and active participation in the therapy, while reducing onerous problems appearing in its course. ${ }^{21,23}$

In addition to psychological problems in patients diagnosed with breast cancer, there are also problems arising as a result of tumor removal surgery. These are mainly the following: postoperative wound pain, lymphoedema of the upper limb of the operated side, weakness, nausea and vomiting as a side effect of anesthesia and postoperative complications. ${ }^{15}$

When caring for the patient after she had a breast tumor removed, the nurse must have a wide range of knowledge of the disease and any associated problems that may arise. Observation of the patient on the " 0 " day after surgery should be thorough and vigilant, focused on early and quick recognition of disturbing ailments or symptoms and an appropriate response. In the course of providing professional care, a nurse should demonstrate skills in fighting current nursing problems and preventing new ones. ${ }^{24}$

The nurse's tasks do not end when the patient is discharged from the ward. It is also important to properly prepare the patient for self-care and self-control at home through education. This way, the nurse teaches the patient to prevent possible postoperative complications, e.g., infection of the postoperative wound or persistence of lymphedema. ${ }^{15,25}$

As the analysis of the above case shows there are many nursing problems in patients diagnosed with breast cancer. They depend on the severity of the disease and the form of treatment used. Despite the fact that malignant tumors are the most common among women, there is no current research on nursing problems occurring in this disease entity. Knowledge of the problems of patients with breast cancer is extremely important in the aspect of professional care provided by nurses. It is worrying that problems occurring in such a large group of cancer patients are not given due attention. One should strive to change this tendency and thus improve the quality of nursing care in oncology.

Summing up the above considerations, it should be emphasized that nursing is a specific profession. During the implementation of tasks and duties, the nurse has the most frequent contact with the patient. Treating each patient individually, nurses devote their time and attention. They gain patients' trust, which is why they are perceived not only as medical workers, but also companions at every stage of hospitalization; both in the diagnostic and therapeutic processes. Establishing a relationship with a patient has a significant effect on the course of the treatment. It allows the appropriate attitudes and behaviours to develop in patients. It should be remembered that nursing care is not only meeting patients' needs, but also creating the right atmosphere. 


\section{Conclusions}

The main problems of the patient diagnosed with breast cancer at the time of admission to the Department of Oncological Surgery were discomfort caused by the necessity of hospitalization and fear of both disability and failure of treatment.

The basic activity that nurses can undertake within the scope of their competence to minimize the current and prevent new nursing problems of a patient with breast cancer is to provide education about the disease, the existing forms of surgical treatment and the advisability of the undertaken medical activities. It is also important to ensure contact with the attending physician and loved ones.

When preparing a patient for surgery to remove a breast tumor, a nurse should inform the patient about the actions taken towards her and explain their purpose, thus obtaining the patient's trust and acceptance. It is important to remind the patient to refrain from taking food and liquids orally. The nurse records basic vital and anthropometric parameters in the fever card. She performs the ECG test. She carries out medical orders, i.e., takes part in pharmacotherapy and diagnostics (laboratory tests including blood type). The nurse prepares the patient mentally and physically: asks the patient to remove jewellery, to take a shower before surgery and to wear a hospital shirt, catheterization. She checks intravenous puncture and changes the dressing to clean and dry.

After surgical removal of the breast tumor, the patient experienced the following problems: postoperative wound pain, lymphoedema of the hand on the operated side, nausea and vomiting after general anesthesia, weakness.

Providing professional nursing care for the patient on the "0" day after surgery to remove the breast tumor requires careful observation to eliminate existing problems and prevent new ones through an accurate diagnosis and an immediate action.

Educating patients and their relatives by nurses in the postoperative period is a part of teaching proper self-care and self-control.

\section{ORCID iDs}

Magdalena Wojtanowska-Kaczka (1) https://orcid.org/0000-0001-5665-1732 Magdalena Babuśka-Roczniak (1) https://orcid.org/0000-0001-9601-8704 Wojciech Roczniak (1) https://orcid.org/0000-0002-6694-9425 Elżbieta Cipora @ https://orcid.org/0000-0002-7794-550X

\section{References}

1. Wysocki P. Oncology Update 2019. Gdańsk, Poland: Via Medica; 2020

2. Jassem J. Rak piersi. In: Krzakowski M, Potemski P, Warzocha K, Wysocki P, eds. Onkologia kliniczna. T 2. Gdańsk, Poland: Via Medica; 2015:643-675.

3. Banuelos-Andrio L, Rodriguez-Caravaca G, Argüelles-Pintos M, Mitjavilla-Casanovas M. Diagnostic validity of the intraoperative analysis in frozen section of the sentinel node in surgical management of breast cancer [in Spanish]. Rev Esp Med Nucl Imagen. 2014;33(4):193-198. doi:10.1016/j.remn.2013.09.002

4. Mendocha J, Stanisławek A. Diagnostyka inwazyjna nowotworów. In: Łuczyk M, Szadowska-Szlachetka Z, Ślusarska B, eds. Standardy i procedury w pielęgniarstwie onkologicznym. Warsaw, Poland: Wydawnictwo Lekarskie PZWL; 2017:86-91.

5. Walaszczyk A, Gabryś D. Markery molekularne stosowane w diagnostyce raka piersi - obecna praktyka kliniczna i perspektywy rozwoju. Nowotwory. 2018;3(5-6):306-314. https://journals.viamedica. pl/biuletyn_pto/article/view/64252. Accessed on September 23, 2020.

6. Krzakowski M, Potemski P, Warzocha K, Wysocki P, eds. Onkologia kliniczna. T 1. Gdańsk, Poland: Via Medica; 2015.

7. Didkowska J, Wojciechowska U, Czaderny K, Olasek P, Ciuba A. Nowotwory złośliwe w Polsce w 2017 roku. Warsaw, Poland: Krajowy Rejestr Nowotworów Złośliwych, Centrum Onkologii - Instytut im. Marii Skłodowskiej-Curie, Ministerstwo Zdrowia; 2019. http://onkologia.org.pl/wp-content/uploads/Nowotwory_2017.pdf. Accessed on September 23, 2020.

8. Cipora E, Konieczny M. Rak piersi u kobiet jako problem zdrowotny współczesnej Europy. Public Health Forum. 2018;2(45):108-114. Accessed on September 23, 2020.

9. https://www.esculap.com/publication/154984/rak-piersi-u-kobietjako-problem-zdrowotny-wspczesnej-europy.

10. Wild ChP, Weiderpass E, Stewart BW. World Cancer Report: Cancer Research for Cancer Prevention. Lyon, France: International Agency for Research on Cancer; 2020.

11. Sygit M. Zdrowie publiczne. Warsaw, Poland: Wolters Kluwer; 2017.

12. Maksymiuk T, Zysnarska M. Zdrowie publiczne w zarysie. Poznań, Polska: Uniwersytet Medyczny im. Karola Marcinkowskiego w Poznaniu; 2015.

13. Głuszek S. Choroby gruczołu piersiowego. In: Głuszek S, ed. Chirurgia - podstawy. Warsaw, Poland: Wydawnictwo Lekarskie PZWL; 2019:183-202.

14. Kita A. Koordynacja jako element nowoczesnej opieki nad pacjentem onkologicznym - specyfika aktywności zawodowej koordynatorów. Zdr Publ Zarządz. 2019;17(2):74-80. doi:10.4467/20842627 OZ.19.009.11380

15. Koper A, ed. Pielęgniarstwo onkologiczne - podręcznik dla studiów medycznych. Warsaw, Poland: Wydawnictwo Lekarskie PZWL; 2011.

16. Ośmiałowska E, Świątoniowska N, Homętowska H. Jakość życia pacjentek z rozpoznaniem nowotworu piersi. Palliat Med Pract. 2018;12(3):143-150. doi:10.5603/PMPI.2018.0003

17. Matyjasek R, Koper A. Rozwój i kierunki rozwoju pielęgniarstwa onkologicznego. In: Łuczyk M, Szadowska-Szlachetka Z, Ślusarska B, eds. Standardy i procedury $w$ pielęgniarstwie onkologicznym. Warsaw, Poland: Wydawnictwo Lekarskie PZWL; 2017:171-177.

18. Didkowska J, Wojciechowska U. Zachorowania i zgony na nowotwory złośliwe w Polsce. Krajowy Rejestr Nowotworów, Narodowy Instytut Onkologii im. Marii Skłodowskiej-Curie - Państwowy Instytut Badawczy. http://onkologia.org.pl/k/epidemiologia/. Accessed on April 16, 2020.

19. Global Cancer Observatory. http://globocan.iarc.fr/Pages/fact_ sheets_population.aspx/. Accessed on April 10, 2020.

20. Besenthal I. Markery nowotworowe. In: Neumeister B, Besenthal I, Böhm BO, eds. Diagnostyka laboratoryjna. Wrocław, Poland: Elsevier; 2013;60-81.

21. Cipora E. Prevention of breast cancer: The importance of screening tests. J Sport Health Sci. 2017;7:1733-1749. doi:10.5281/zenodo. 1202415

22. Cipora E, Konieczny M, Sobieszczański J. Acceptance of illness by women with breast cancer. Ann Agric Environ Med. 2018;25(1): 167-171. doi:10.26444/aaem/75876

23. Cipora E, Konieczny M, Karwat ID, Roczniak W, Babuśka-Roczniak M. Surgical method of treatment and level of satisfaction with life among women diagnosed with breast cancer, according to time elapsed since performance of surgery. Ann Agric Environ Med. 2018;25(3):453-459. doi:10.26444/aaem/91586

24. Cipora E, Konieczny M, Karwat ID, Roczniak W, Babuśka-Roczniak M. Satisfaction with life among women with breast cancer: Selected demographic and social factors. Ann Agric Environ Med. 2018;25(2):314-319. doi:10.26444/aaem/82622

25. Jankau J, Hodorowicz-Zaniewska D. Chirurgia onkoplastyczna sutka. Med Prakt Chir. 2014;1:53-57.

26. Farbicka PE, Nowicki A, Krzemkowska E. Wiedza o zachowaniach prozdrowotnych i chorobie kobiet operowanych z powodu raka piersi. Piel Zdr Publ. 2016;6(2):119-126. doi:10.17219/pzp/61708 